\title{
The Role of Contingency Factors in the Implementation of Strategic Management Accounting (SMA) in Private Universities/Colleges (PTSes) under Kopertis Region V of Yogyakarta
}

\author{
Sriyono $^{1}$ and Rahmawati ${ }^{2}$ \\ ${ }^{1}$ Pembangunan Nasional University "Veteran” Yogyakarta-Indonesia \\ ${ }^{2}$ Sebelas Maret University Solo-Indonesia \\ E-mail: 'sriyono_upnvy@yahoo.com, ${ }^{2}$ rahmaw2005@yahoo.com
}

\begin{abstract}
Strategic Management Accounting (SMA) is an interesting subject to study since differences exist in views on the concept of SMA and the fact that studies on public sector organization in Indonesia remain somewhat rare. Contingency theory holds that organizational structure and system represent function of environment and a company-specific factor. Therefore, the development of SMA in organizations needs to take contingency factors into account. While the results of analysis indicate that private universities/colleges (subsequently abbreviated to PTS) under Coordinating Body for Private Colleges (subsequently referred to as Kopertis) Region V of Yogyakarta have implemented SMA, they have not fully considered the contingency factors. Strategic-type contingency factors and market orientation have significant effect on SMA at 5\% and $10 \%$, respectively. On the contrary, Deliberate Strategy has no significant effect on SMA in PTSes under Kopertis of Region V of Yogyakarta.
\end{abstract}

Keywords: Contingency, Strategic Management Accounting, Deliberate, Market Orientation.

\section{INTRODUCTION}

The development of strategic management accounting (SMA) research is rooted in a basic consideration of the increasingly relevant information beyond the boundaries of companies [18]. SMA is a general approach to integrating an understanding / insight into accounting management and marketing management within the framework of strategic management [17]. Simon and guilding [20] view SMA from two perspectives: SMA as it is understood as a set of strategically-oriented accounting techniques and SMA as it is seen as accountant involvement in the strategic decision-making process of the company. Lack of consensus concerning SMA concepts made SMA research an interesting effort to do. The use of information on SMA may help managers in adopting and implementing organizational schemes in response to the environment, as well as help them in decision making and devising corporate strategy to achieve organizational objectives [12]. SMA techniques have not been widely adopted and no SMA terms understandably or widely used thus far, despite the fact that the aspects of SMA influence the way we think, language of business, and the way we do the business [22]. The use and development of SMA techniques have been associated with the issue of external information needs to deal with the uncertainty of the environment and to support strategic decisions. In contingency theory, organizational structure and system represent an environmental function of a company-specific factor [1],[7]. This is exactly why the development of SMA in organizations needs to consider contingency factors. Contingency approach argued that organizational effectiveness builds upon correspondence between the organization and its environment. According Outley [16], no organizational design universally applicable that represents the basic concept in contingency theory. This indicates that the 
application of organizational design (organizational structure, SMA, etc) in some organizations differs from that in some others. Based on the above described background and phenomena, the problem formulation will be as follows: Do contingency factors, which consist of strategy type, deliberate strategy, and market orientation, affect the implementation of SMA in Private Colleges of Kopertis Region V of Yogyakarta?

\section{LITERATURE REVIEW AND HYPOTHESIS DEVELOPMENT}

According to Otley [16], contingency theory can be used to analyze the management accounting design and system employed to provide and deliver companies with information for multiple purposes. Contingency theory is applied by management accounting researchers to answer the questions concerning the correspondence between the control and organizational structure; influence on performance; and investigation of the contingency factors as well as their influence on the performance [10]. Roslender and Hart [17] define SMA as a generic approach to integrating understanding/insight into managerial accounting and marketing management in the framework of strategic management. Simon and Guilding [20] define SMA from two perspectives: as a set of accounting techniques oriented to strategy, and as accountant involvement in the company's strategic decision making processes. Simmonds [16] defines SMA as: "A form of management accounting in which emphasis is placed on information which relates to factors external to the firm, as well as non-financial information and internally generated information".

Companies that implement a differentiation strategy adopt a tight budget, a formal output monitoring and forecast data [21]. The use of SMA information can help managers to adopt and implement the organization's plans in response to the environment, as well as helping with them in making decisions and devising the company's strategy to achieve the organizational objectives [12]. Changes in cost accounting and management accounting practices are related to contingency factors [7]. Guilding and Lisa [5] found positive an association between market orientation and customer accounting, and a positive but insignificant relationship between competitive intensity and customer accounting. Roslender and Hart [17] found an association between SMA practices in the UK and management accounting and marketing management practices. Strategic conformity exists between Business-Government
Relations strategy and Business-Government Relations structure that lead to improvement in Business-Government Relation performance [11]. Contingency factors in strategic positioning strategic mission are related to the use of SMA techniques in large manufacturing companies in Italia [2]. Strategic position plays a contingency role in the use of SMA techniques [3]. Corporate strategy has a significant impact on the successful implementation of SMA in large companies in Slovenia [20]. SMA Information plays an important role in strategic purposes, especially in dealing with competition and implementing strategy for Electrical and Electronics companies in Malaysia [15]. Based on the above conceptual framework, the hypotheses developed in this study will be as follows:

\section{$\mathrm{H}_{1}$ : The Contingency Factors - Strategic Type (ST) influences the SMA in PTSes under Kopertis Region V of Yogyakarta. \\ $\mathrm{H}_{2}$ : The Contingency Factors - Deliberate Strategy (DS) influences the SMA in PTSes under Kopertis Region V of Yogyakarta. \\ $\mathrm{H}_{3:} \quad$ The Contingency Factors - Market Orientation (MO) influences the SMA in PTSes under Kopertis Region V of Yogyakarta.}

\section{RESEARCH METHOD}

\subsection{Object and Sample}

Objects in this study are private colleges (PTSes) under Kopertis Region V Yogyakarta, and the samples are heads of college department. The samples are obtained using the purposive sampling method. The eligibility criteria for the samples are: heads of college department, familiar with the strategy selected and applied in their colleges, and experienced in directing college department in both financial and non-financial affairs.

\subsection{Measurement Variables}

Measurement of strategic type, according to Porter, consists of cost leadership and differentiation strategies [4]. Deliberate strategy is a strategy offered by managers as a plan to respond to external challenges [6]. Deliberate strategy is measured using Minztberg' instruments [13]: strategic decision makers, intention strategic and strategic action. Market orientation is measured using instrument developed by Narver \& Slater [14], which consists of: Customer Orientation, Competitor Orientation and Inter functional 
Coordination. Contingency factors in this study are measured using 5-point Likert scale for respondent: (1) strongly disagree, (2) disagree, (3) neutral, (4) agree, and (5) strongly agree [6], [13], [14].

Strategic management accounting is as a set of strategically-oriented accounting techniques, and represents accountant involvement in the strategic decision-making process of the company [20]. The instrument used to measure SMA in this study is a 5-point Likert scale: (1) never, (2) rarely, (3) occasionally, (4) a moderate amount and (5) every time [20].

\subsection{Data Analysis Techniques}

Hypothesis testing was conducted using a multiple regression analysis. Classical Assumption Test was conducted with reference to Hair et al. [8]. Factors or components analysis is in general performed to reduce the data and interpret them as a new variable applicable to new dimensions of SMA.

\section{RESULTS AND DISCUSSION}

Of 250 questionnaires distributed, the number of questionnaires returned amounts to only 60 . And of the 60 returned questionnaires, two are incomplete, therefore excluded from the subsequent process. Thus, the remaining questioners amounted to only 58.

Validity testing for all indicator variables indicated that the significance level for correlation between instrument and indicator of Contingency Factors and SMA is less than 0.05, except the significance level of the first indicator of Strategic Type (ST1) of 0.133 and the third indicator of Strategic Type (ST3) of 0.075 (less than 0.05). It can be concluded from this result that all indicators, except for ST1 and ST3, are valid. The reliability testing for all instruments of Contingency Factors and SMA indicated a Cronbach's Alpha coefficient of 0.5 . Therefore, it can be concluded that all of the instruments employed in this study are reliable. The results of classical assumption testing indicated that all of the classical assumptions are met, i.e., no multicollinearity problem, no autocorrelation, no heteroscedasticity were found, and that the data were normally distributed.

\subsection{Factor Analysis Results}

Factor analysis results indicate that the component value of SMA factors for each factors are as follows: strategic costing (0.700); strategic planning, control and performance measurement (0.723); strategic decision-making (0.717); competitor accounting (0.741); and customer accounting $(0.771)$, which is less than 0.5 . These results indicate that strategic costing; strategic planning, control and performance measurement; strategic decision-making; competitor accounting; and customer accounting are members of strategic factors of management accounting.

\subsection{Hypothesis Testing Results}

The results of Strategic Type influence of SMA indicated that the significance level (p) is 0.001 (Table 4). This indicates that statistically the Strategic Type have a significant influence on SMA in PTSes under Kopertis Region V of Yogyakarta (Hypothesis 1 is supported). Heads of college department take strategic type selected into account in developing and implementing SMA in colleges. PTSes under Kopertis Region V of Yogyakarta inclined to implement strategic type - cost leadership strategies. From this we can conclude that colleges that implement Strategic Type - Cost Leadership tend to implement SMA. These results support the [7],[11],[15],[17],[19],[20] studies.

The test results of deliberate strategy influence on SMA indicated the significance level of 0.438 (Table 4). This leads us to conclude that Deliberate Strategy is statistically has no influence on SMA in colleges (PTSes) under Kopertis Region V of Yogyakarta (Hypothesis 2 not supported). This means that the strategies developed by college administrators in response to external environmental challenges (deliberate Strategy) have not been considered in the development and implementation of SMA. While the devising of strategies to respond to external environmental challenges indicated that the strategic decision makers have anticipated the future strategic actions, and the implementation of planned strategies may have been a slight deviation, and the strategic planning that is based on the disadvantages of the planned strategies, such conditions do not influence the development and implementation of SMA in PTSes under Kopertis Region V of Yogyakarta. These results support those of [7],[11],[12],[15],[17],[19],[20] studies.

The results of the test of Market Orientation influence on SMA indicated the significance level of 0.087 (Table 4), which is higher than 0.05 and lesser than $0.1(10 \%)$. From this, it can be concluded that Market Orientation is statistically, at significance level of $10 \%$, significantly influenced the SMA in PTSes under Kopertis Region V of Yogyakarta (Hypothesis 3 is supported). This would mean that in the development and implementation of SMA in PTSes under Kopertis Region V of Yogyakarta, Contingency Factors - 
Market Orientation have been taken into account by college management. The results support those of [17],[19],[20] studies.

Table 1: The Results of Test of Contingency Factors (Strategic Type, Deliberate Strategy, and Market Orientation) influence on SMA.

\begin{tabular}{|c|c|c|c|c|c|}
\hline \multirow{2}{*}{$\begin{array}{c}\begin{array}{c}\text { Independent } \\
\text { Variables }\end{array} \\
\text { Strategic Type }\end{array}$} & \multirow[b]{2}{*}{$---->$} & \multirow[b]{2}{*}{ Strategic Management Accounting (SMA) } & \multicolumn{2}{|c|}{$\begin{array}{l}\text { Standardized } \\
\text { Coefficients }\end{array}$} & \multirow{2}{*}{$\frac{\mathbf{p}}{0.001}$} \\
\hline & & & 0.447 & * & \\
\hline Deliberate Strategy & $---->>$ & Strategic Management Accounting (SMA) & $(0.093)$ & & 0.438 \\
\hline Market Orientation & $---->>$ & Strategic Management Accounting (SMA) & 0.232 & $* *$ & 0.087 \\
\hline$R$-Square & 0,330 & & & & \\
\hline $\mathrm{F}$ & 8.877 & & & & \\
\hline Sig.F & 0,000 & & & & \\
\hline \multicolumn{6}{|l|}{$*$ significant $5 \%$} \\
\hline \multicolumn{6}{|l|}{ ** significant $10 \%$} \\
\hline Source: Data are pr & & & & & \\
\hline
\end{tabular}

\section{CONCLUSION}

Based on the data analysis, we draw the conclusion as follows:

1. Contingency Factor - Strategic Type is significantly influence the SMA in Private Colleges (PTSes) under Kopertis Region V of Yogyakarta

2. Contingency Factor - Deliberate Strategy (DS) have no significant influence on SMA in PTSes under Kopertis Region $\mathrm{V}$ of Yogyakarta.

3. Contingency Factor - Market Orientation (MO) is significantly influence (at significant level of 10\%) the Strategic Management Accounting in PTSes under Kopertis Region V of Yogyakarta.

\section{REFERENCES}

[1] Chenhall, R. H., 2003, Management control system design within its organizational context: Findings from contingency-based research and directions for the future. Accounting, Organizations and Society 28 (23): 127-168.

[2] Cinquini, Lino and A. Tenucci, 2006, Strategic Management Accounting: exploring distinctive features and links with strategy. Munich Personal Repec Archive.

[3] Cinquini, Lino, and A. Tenucci, 2007, Is The Adoption Of Strategic Management Accounting Techniques Really "StrategyDriven"? Evidence from A Survey. Cost and
Performance in Services and Operations Trento (Italy).

[4] David, Fred, R., 2005, Strategic Management Concepts and Cases tenth edition. Pearson Prentice HallTM.

[5] Guilding, Chris and L. McManus, 2002, The incidence, perceived merit and antecedentsn of customer accounting an exploratory note. Accounting, Organizations and Society.

[6] Haberberg, Adrian and Alison Rieple, 2008. "What is Strategic Management dalam Strategic Management: Theory and Application", Oxford: Oxford University Press

[7] Haldma, Toomas and Kertu Laats, 2002, Contingencies Influencing the Management Accounting Practices of Estonian Manufacturing Companies. Management Accounting Research, Vol. 13, No. 4.

[8] Hair F. H.; E. A. Anderson; R. L. Tathan, and W. C. Black, 2000, Multivariate Data Analysis, Macmillan Publishing Company, New York.

[9] Hyvönen, Johanna., 2008, Linking Management Accounting And Control Systems, Strategy, Information Technology, Manufacturing Technology And Organizational Performance Of The Firm In Contingency Framework. Academic dissertation to be presented, with the assent of the Faculty of Economics and Business Administration of the University of Oulu, for public defence in Auditorium TA105, Linnanmaa, on February 8th.

[10] Islam, Jesmin and Hui H., 2012, A review of literature on contingency theory in managerial accounting. African Journal of Business Management. Vol. 6(15.

[11] Meznar, M. B. and Julius H. J. Jr., 2005, Business \& Society Business-Government Relations With in a Contingency Theory Framework: Strategy, Structure, Fit, and Performance. Business Society; 44; 119

[12]Mia, L and B. Clarke, 1999, Market Competition, Management Accounting Systems and Business Unit Performance. Management Accounting Research. Vol.10. 137-158

[13] Mintzberg, H. and Water J. A., 1985, Of Strategies, Deliberate and Emergent. Strategic Management Journal. No 6.

[14] Narver, John C. and S. F. Slater, 1990, The Effect of Market Orientation on Business Profitability, Journal of Marketing, October, p. 20-35.

[15] Noordin, Raman, and Y. Zainuddin, M. Tayles, 2009, Strategic Management Accounting 
Information Elements: Malaysian Evidence. Asia-Pacific Management Accounting Journal. Vol. 4. Issue 1, 17-34.

[16] Otley, David. T., 1980, The Contingency Theory of Management Accounting: Achievement and Prognosis. Accounting Organization and Society. Vol. 5.

[17] Roslender, Robin and Susan J. H., 2003, In Search Of Strategic Management Accounting: Theoretical and Field Study Perspectives. Management Accounting Research.

[18] Simmonds, K., 1981, Strategic Management Accounting. Management Accounting, 59.

[19] Simon, Cadez, 2007, A Configuration Form Of Fit In Management Accounting Contingency Theory: An Empirical Investigation. The Business Review, Cambridge. ABI/INFORM Research.

[20] Simon, Cadez and Guilding C., 2008, Strategy and Strategic Management Accounting: An Investigation of Organizational Configurations. Manchester Business School Research.

[21] Simons, R., 1987, Accounting control systems and business strategy: an empirical analysis. Accounting, Organizations and Society, 12, 357-374.

[22] Smith, Kim Langfield, 2008, Strategic management accounting: how far have we come in 25 years? Accounting, Auditing \& Accountability Journal. Vol. 21 Iss: 2. p. $204-$ 228. 